\title{
Meu caminho para Heidegger. Ou: a metafísica e o apelo da questão do ser*
}

\author{
My Path to Heidegger. Or: Metaphysics and the Appeal of the \\ Question of Being
}

Fernando Costa Mattos

fcmattos1974@gmail.com

(Universidade Federal do ABC, São Paulo, Brasil)

\begin{abstract}
Resumo: Este artigo retraça um caminho de pesquisa na filosofia alemã, o qual passa por Kant, Nietzsche e, depois de um desvio pela controvérsia entre Habermas e Dieter Henrich nos anos 1980, desemboca em Heidegger. 0 foco da reflexão é a questão da metafísica, ou, mais especificamente, o modo como o problema da metafísica é enfrentado por cada um desses autores. Se, em Kant, a metafísica deixa de ser um discurso sobre objetos e passa a tratar de ideias (as quais, em todo caso, podem ainda ser objetos de crença), em Nietzsche ela seria, enquanto cosmologia, concebida por oposição à visão cristã de mundo, mas também sem afirmar objetos propriamente ditos. 0 assunto é retomado na cena contemporânea por Dieter Henrich, que se contrapõe à ideia habermasiana de um pensamento pós-metafísico e aponta para a necessidade de reavivar o campo da metafísica em linha com o que alguns autores teriam feito no século XX - notadamente Martin Heidegger, para quem a ontologia demanda uma nova linguagem, capaz de exprimir o ser enquanto tal.
\end{abstract}

Palavras-chave: Kant; Nietzsche; Heidegger; metafísica; ontologia.

\begin{abstract}
This paper traces a path of research in German philosophy, which passes by Kant, Nietzsche and, after a deviation through the controversy between Habermas and Dieter Henrich in the 1980s, ends in Heidegger. The focus of the reflection is the question of metaphysics, or, more specifically, how the problem of metaphysics is faced by each of these authors. If, in Kant, metaphysics ceases to be a discourse on objects and starts to deal with ideas (which in any case may still be objects of belief), in Nietzsche it would be, as cosmology, conceived in opposition to the Christian worldview, but also without affirming objects. The issue is taken up again in the contemporary scene by Dieter Henrich, who contrasts with the Habermasian idea of a post-metaphysical thought and points to the need to revive the field of metaphysics, in line with what some authors have done in the twentieth century - notably Martin Heidegger, for whom ontology demands a new language, capable of expressing being as such.
\end{abstract}

Keywords: Kant; Nietzsche; Heidegger; metaphysics; ontology.

DOI: http://dx.doi.org/10.11606/issn.2318-9800.v23i2p53-66

\section{Kant e a necessidade (Bedürfniss) de acreditar nas ideias metafísicas}

Um dos principais pilares do sistema kantiano, como se sabe, é a distinção por ele efetuada entre fenômeno e coisa em si: devemos considerar os objetos ora como

\footnotetext{
* Versão modificada de uma aula proferida em 16/02/2016, como abertura da disciplina "Fenomenologia e Filosofia Hermenêutica", do Bacharelado em Filosofia da UFABC.
} 
aparecem para nós, isto é, como fenômenos (Erscheinungen, "aparecimentos"), ora como seriam em si mesmos, independentemente do modo como os percebemos em função de nossas condições subjetivas de apreensão (cf. Mattos, 1999). Ao fazer essa distinção, Kant tem um duplo objetivo (correspondente às funções negativa e positiva da Crítica da razão pura, nos termos de seu segundo prefácio) (cf. Hulshof, 2013): assegurar necessidade e universalidade ao conhecimento científico, resultado da aplicação dos conceitos puros do entendimento aos objetos enquanto fenômenos, apreendidos na intuição sensível, e, ao mesmo tempo, evitar que o ponto de vista empírico, ou seja, esse que diz respeito ao domínio fenomênico, seja estendido à realidade como um todo. Se não temos acesso cognitivo àquilo que está para além da experiência sensível, àquilo que diz respeito às coisas em si mesmas, ao mundo em si mesmo, então não podemos, em princípio, nem afirmar nem negar qualquer coisa a respeito desse hipotético domínio (que seria, portanto, o domínio do não-material).

Evidentemente, esse duplo objetivo não é alcançado somente com a distinção fenômeno x coisa em si: boa parte da Crítica da razão pura será dedicada à tarefa de mostrar como o conhecimento se constitui na articulação da sensibilidade, cujas formas subjetivas são o espaço e o tempo (tematizadas na "Estética transcendental"), com o entendimento, cujos conceitos teriam sua realidade objetiva comprovada na "Dedução transcendental” (cf. Kant, 2012, p. 128 e ss. (B 129 e ss.)). Conforme a célebre fórmula, intuições (sensíveis) sem conceitos são cegas, conceitos sem intuições são vazios (idem, p. 97 (B 75)): é na junção de ambos que se dá o conhecimento empírico, superando-se com isso a oposição entre racionalistas e empiristas, que dominava o cenário filosófico da época, e permitindo-se explicar a física matemática, que vinha de firmar-se nas teorias de Copérnico, Galileu, Kepler e Newton.

Mas o objetivo principal de Kant, segundo ele mesmo tantas vezes afirmou, não era o de assegurar os fundamentos do conhecimento científico (por maior que fosse a importância disso): o que mais o preocupara, quando despertado por Hume do sono dogmático (conforme a sua tão citada metáfora), ${ }^{1}$ eram as possíveis consequências do empirismo para a moralidade e, por que não reconhecê-lo de saída?, para a própria metafísica (ou seja, a reflexão sobre o ser enquanto tal e seus desdobramentos nos temas clássicos desse âmbito da filosofia). Se a realidade do mundo, considerada como um todo, se reduzisse ao domínio do observável (a experiência, a matéria, o mundo fenomênico), então as leis morais, que dizem respeito não a como o mundo é, mas a como o mundo deve - ou deveria - ser, não passariam de quimeras inventadas pela mente humana. Era preciso, portanto, demonstrar que o mundo não se reduz àquele domínio em que se articulam conceitos e intuições, produzindo juízos cognitivos determinantes: há esferas do real que se subtraem a essa operação mental que

1 Kant emprega essa metáfora ao descrever a influência de Hume sobre suas investigações no prefácio aos Prolegômenos a toda metafísica futura (Prol., Ak.IV, 260.). 
predomina na atividade científica; esferas que podem - se é que não devem - ser pensadas sob outros critérios.

Ora! Ao assegurar o domínio do "em si” como um domínio que não pode ser acessado pela via do conhecimento teórico, Kant abriu ao mesmo tempo todo um espaço para a nossa reflexão sobre o mundo - e sobre a nossa relação com ele - onde o nosso modo de proceder poderia pautar-se por critérios distintos daqueles que orientam, digamos, o olhar perscrutador do experimento científico. Que critérios? Eis a evidente questão que se punha a Kant, e que ele buscaria responder com base no exame de nossa constituição subjetiva (a mesma, aliás, que lhe coubera investigar quando se tratava do próprio conhecimento empírico): nossa experiência mostra - e Kant não hesitaria em admitir tratar-se de nossa experiência histórica ${ }^{2}$ - que a vida humana, aqui incluída a nossa relação com o mundo exterior, sempre esteve longe de reduzir-se à, digamos, contemplação desinteressada da natureza, ou ao conhecimento supostamente objetivo das coisas tal como aparecem aos nossos sentidos.

Muito pelo contrário: parte substantiva da vida humana diz respeito a como viver nesse mundo, um mundo que, afinal, só conhecemos até certo ponto; diz respeito, em outras palavras, a qual a maneira mais correta de viver; ou seja, à questão moral por excelência. E, segundo Kant, a tal investigação da subjetividade humana permitiria identificar, sob a notória variedade de costumes e valores socialmente constituídos, nos diversos locais e épocas da história humana, um princípio supremo da moralidade, a saber, o imperativo categórico - cuja fórmula, bem conhecida, diz que devemos sempre agir segundo uma máxima (i.e. uma regra subjetiva da ação) que pudéssemos querer que fosse ao mesmo tempo uma lei universal, ou seja, uma lei válida para todos os seres humanos (cf. Kant, 2009, p. 215 (Ak.IV, 421)). E esse princípio, como sabemos, permitiria a Kant fundar uma moral universal e, a partir dela, deduzir uma doutrina do direito e uma doutrina da virtude, com critérios claros para pensar uma sociedade justa a ser perseguida historicamente (como um ideal regulador a nos determinar uma tarefa infinita etc.) (cf. Kant, 2013).

Sem entrar por ora no mérito de saber se tal princípio - o imperativo categórico - é mesmo um princípio de caráter universal, válido para todo e qualquer ser humano, em toda e qualquer época histórica (como um conhecimento matemático ou uma lei da física), o que me importa salientar é o fato de ele servir não apenas como critério regulador para o agir humano, mas também como base, enquanto indício da nossa natureza moral, para o pensar humano acerca daquele domínio do real que escapa à determinação empírica dos objetos enquanto fenômenos. Começando pela liberdade como propriedade de nossa própria vontade, sem a qual a moralidade seria

2 Quanto a isso, vale conferir o que diz Kant na "História da razão pura", na "Doutrina do Método" da Crítica da razão pura (cf. Kant, 2012, p. 612 e ss. (B 880 e ss.)). 
impossível (donde esta ser descrita, numa famosa nota do prefácio à segunda Crítica, como ratio cognoscendi daquela, e aquela como ratio essendi desta) (Kant, 2016, p. 17 (Ak.V, 4)), o que norteia a reflexão kantiana sobre o suprassensível (e a imagem do "nortear" é plenamente conforme, diga-se de passagem, ao que ele diz no opúsculo Como orientar-se no pensamento?) $)^{3}$ é justamente a nossa natureza moral, que nos leva a necessitar - ou carecer, como uma tradução mais precisa de bedürfen - de uma convicção íntima a respeito não apenas da liberdade, pela razão que acabamos de indicar, mas também da imortalidade de nossa alma e da existência de Deus.

Tal é, com efeito, o caminho de pensamento percorrido por Kant na segunda parte da sua Crítica da razão prática: uma vez que nos percebemos como seres finitos num mundo desprovido de sentido aparente (fenomênico), mas ao mesmo tempo nos reconhecemos como seres dotados de uma consciência moral (que nos leva, por exemplo, a discernir o certo do errado, a sentir arrependimento quando erramos, a admirar quem age de maneira justa, e assim por diante) - a qual, por seu turno, pressupõe um fundamento existencial distinto do mero fenômeno (nosso corpo) -, somos levados a acreditar - sem que qualquer conhecimento empírico possa refutar esta crença - que nossa essência, nosso “eu em si” (para usar os termos da terceira seção da Fundamentação) (Kant, 2009, p. 373 e ss. (Ak.IV, 453 e ss.)), é o verdadeiro fundamento de nossa existência sensível; nosso "eu numênico", cuja natureza é distinta daquela do "eu fenomênico". Em outras palavras: somos uma alma imortal que se manifesta no mundo sensível através da liberdade, mas cuja plena realização moral só pode ser pensada em termos infinitos - donde a necessidade de acreditar também em Deus como um autor moral do mundo, a garantir aquele sentido de que o mundo fenomênico não nos dá mostras (cf. Mattos, 2009, p. 147 e ss).

Tais ideias metafísicas - Deus, alma e liberdade - não são, evidentemente, objetos de um conhecimento teórico, já que não resultam da conjunção de um conceito do entendimento com uma intuição sensível. Visto, porém, que são possíveis (pois também não podem ser refutadas por conhecimento algum), e necessárias do ponto de vista moral, elas adquirem o estatuto de postulados da razão prática, os quais, enquanto objetos de nossa fé ou crença racional, constituem um outro tipo de conhecimento; um conhecimento a que Kant deu o nome de "conhecimento prático" e que, de resto, permite compreender a célebre afirmação do segundo prefácio à Crítica da razão pura segundo a qual Kant teve de "suspender o saber para dar lugar à fé” (Kant, 2012, p. 37 (B XXX)). Ou seja: o saber, o conhecimento teórico, tem o seu lugar devidamente assegurado no sistema dos conhecimentos humanos, mas ele só vai até um certo ponto; além deste ponto, já não é ele quem dita as regras, mas sim a fé, isto é, a crença - racionalmente justificada - em ideias sem as quais o mundo não faria sentido e a moral se tornaria uma quimera vazia.

3 Kant, I. Was heisst: sich im Denken orientieren? Ak. VIII, 131 e ss. 
Em que pesem as muitas nuanças deixadas aqui de lado, eu queria chamar a atenção para esse movimento do pensamento kantiano que, longe de acabar com a metafísica (como quereriam tantos de seus intérpretes, Lebrun entre eles), ${ }^{4}$ assegura-lhe antes - em uma chave radicalmente nova, é verdade - uma notável sobrevida, se não mesmo um renascimento (como quereriam outros intérpretes, entre eles Leo Freuler (1992)). E não porque o conhecimento teórico nos tenha dado acesso a um novo tipo de realidade, ou à explicação última dos fenômenos mundanos (como pretendia a velha metafísica), mas sim porque se reconheceu a necessidade de sentido como um elemento constitutivo da experiência humana subjetiva: dada a nossa natureza, temos necessidade de acreditar em algo que dê um sentido à existência. Sem isso, perderíamos - ouso dizê-lo! - a própria vontade de viver.

\section{Nietzsche e a cosmologia da vontade de poder: libertando o indivíduo das amarras judaico-cristãs}

Sim, estou sendo dramático - quiçá “trágico" - na escolha dos termos; mas não o estou sendo de maneira fortuita. Com esses termos, preparo o salto que nos conduz a Nietzsche. Afinal, também ele, o “filósofo das marteladas", estava preocupado com a questão do sentido (que se leia, quanto a isto, a última seção da Genealogia da moral); e também ele, como Kant, espreitava o risco do mais radical niilismo como uma possibilidade, um desdobramento, inscrito em nossa época histórica (a "época da crítica", nos conhecidos termos do primeiro prefácio à Crítica da razão pura, seria também - e talvez inevitavelmente - a época da “morte de Deus", conforme o igualmente célebre diagnóstico de Nietzsche). No fim das contas, a problemática teórica de Nietzsche não seria tão distinta daquela de Kant, como a princípio se costuma pensar (cf. Mattos, 2013).

É evidente que as diferenças entre os filósofos são muitas, sobretudo nos pressupostos assumidos: se Kant ainda se vale de uma concepção universal da natureza humana, responsável por embasar a investigação de nossas faculdades e o tal «conhecimento prático» como uma espécie de sucedâneo da velha metafísica, Nietzsche já não pode, cem anos depois, recorrer a tamanha pretensão cognitiva no que diz respeito ao, digamos, autoconhecimento do ser humano. Não existe uma moral, por exemplo, como ele insistirá em dizer, mas sim muitas e variadas morais, ${ }^{5}$ inclusive no que diz respeito aos seus respectivos princípios supremos: o

\footnotetext{
4 Refiro-me ao Lebrun de Kant e o fim da metafísica, já que, em textos posteriores (como aqueles reunidos em Sobre Kant), o mesmo Lebrun acentuaria o caráter metafísico e cristão do pensamento kantiano. Cf. Lebrun, 2002 e 1993.

5 "Moral é hoje, na Europa, moral de animal-de-rebanho: portanto, como entendemos as coisas, somente uma espécie de moral humana, ao lado da qual, antes da qual, depois da qual, muitas outras morais e, antes de tudo, morais superiores são possíveis, ou deveriam ser" (Nietzsche, "Para além de bem e mal”, seção 202, in: Nietzsche, 1980).
} 
imperativo categórico the faz rir, como diz numa conhecida passagem, ${ }^{6}$ justamente por pretender-se universal, por aspirar a uma validade para todos os seres humanos em todos os locais e épocas do mundo. Isso não quer dizer que o ser humano não seja um animal moral, que ele não valore ou não precise valorar as coisas do mundo: ele de fato o é, e é isso que nos afirma o conceito nietzschiano de vontade de poder - nós lutamos e disputamos pela afirmação de nosso modo de valorar, frente a outros modos de fazê-lo. A questão é que não há um critério correto, um princípio metaético, por assim dizer, que pudesse estabelecer, entre os valores concorrentes, qual é correto e qual é errado.

Como se sabe, a filosofia de Nietzsche se coloca "além do bem e do mal" por colocar-se além do "verdadeiro" e do "falso": é a impossibilidade de definir a verdade e a falsidade dos enunciados - já que todos os enunciados são meramente interpretativos, são perspectivas - que torna impossível definir quaisquer outros critérios binários do tipo (correto-incorreto, belo-feio etc.) (cf. Mattos, 2013, p. 25 e ss). Se Kant havia dito, acertadamente (como reconhece Nietzsche na seção 357 de $A$ gaia ciência), ${ }^{7}$ que não podemos conhecer as coisas como são em si mesmas, ter-lhe-ia faltado dar um passo adiante para reconhecer que o próprio conhecimento empírico, das coisas como fenômenos (isto é, das coisas tal como as percebemos através dos sentidos, e tal como as julgamos a partir de certos conceitos), é também uma mera interpretação, a mostrar-nos tão somente, digamos, certos aspectos da realidade. Ter-lhe-ia faltado reconhecer, em última instância, o caráter relativo de toda interpretação discursiva da realidade, inclusive daquela que se teria estabelecido como dominante na história da filosofia e da ciência ocidentais - tanto a física de Newton como a biologia de Darwin, por exemplo, ambas muito bem conhecidas de Nietzsche, teriam de ser reconhecidas como interpretações da realidade, e não como suas descrições verdadeiras (cf. Nietzsche, 2001, p. 222 e ss. Seção 335, "Viva a física!").

Se Kant já havia apontado, pois - na esteira de Descartes e Leibniz, diga-se de passagem -, para o caráter essencialmente subjetivo do conhecimento humano,

6 "E agora não me venhas falar do imperativo categórico, meu amigo! - essa palavra faz cócegas em meu ouvido, e tenho de rir, a despeito de tua presença tão séria: faz-me pensar no velho Kant, que como castigo por ter-se apossado sub-repticiamente da 'coisa em si' - também uma coisa muito ridícula! - foi sub-repticiamente apanhado pelo 'imperativo categórico' e com ele no coração extraviou-se e voltou outra vez para 'Deus', 'alma', 'liberdade' e 'imortalidade', igual a uma raposa que se extravia e volta para sua jaula: - e eram sua força e esperteza que haviam arrombado essa jaula!" (Nietzsche, "A gaia ciência”, seção 335, in: Nietzsche, 2001).

7 Nesse parágrafo, Nietzsche diz: "como alemães duvidamos, juntamente com Kant, da validade última dos conhecimentos das persciências naturais e de tudo o que se deixa conhecer causaliter: o cognoscível já nos parece, como tal, de pouco valor". Pouco antes ele recordara, como positiva, "a enorme interrogação de Kant, por ele aplicada ao conceito de 'causalidade' - não que ele houvesse, como Hume, questionado a sua legitimidade: ele começou, isto sim, a delimitar cautelosamente o âmbito no qual esse conceito faz sentido (ainda hoje não se terminou com essa demarcação)" (Nietzsche, 2001). 
assinalando o pertencimento de categorias como causa e substância ao entendimento humano (e não à própria realidade), mas acreditava ainda na possibilidade de um conhecimento absolutamente válido da subjetividade humana (nosso sistema de faculdades mentais, cuja análise completa ele teria efetuado em sua obra crítica), Nietzsche dá um passo além e relativiza também esse nosso autoconhecimento, enfatizando o caráter situado, isto é, histórica e culturalmente situado, de toda abordagem teórica do mundo e do ser humano. Nós somos, de fato, intérpretes da realidade (somos "homens do conhecimento"), e somos, de fato, intérpretes valoradores da realidade (somos "homens morais"); mas nossas interpretações e valorações são infinitamente variadas e variáveis - donde o mundo ter voltado a ser "infinito para nós". 8

Desse ponto de vista - e esta é, de fato, uma interpretação peculiar da obra nietzschiana (comum a autores como Friedrich Kaulbach, Volker Gerhardt e Antonio Marques) (cf. Mattos, 2007) -, poderíamos dizer que, na passagem de Kant a Nietzsche, o que ocorre é uma transição do sujeito transcendental para o que se poderia caracterizar como um "foco perspectivador singular", algo que pode coincidir com o indivíduo (Immanuel Kant, Friedrich Nietzsche ou Fulano de Tal), mas pode ser também uma época (como a própria época moderna), uma civilização (como a ocidental), um povo (como o alemão, talvez?), um grupo, etc. Isso supõe, de todo modo, que Nietzsche opera com uma distinção entre o ponto de vista do intérprete e a realidade interpretada - uma distinção que muitos comentadores recusam (cf., por exemplo, Marton, 2000), e cuja supressão, como veremos, permitiria aproximar as filosofias de Nietzsche e Heidegger. Mas é o preço que pagamos, de certo modo, para poder compreender no interior da tradição iluminista o projeto nietzschiano de uma "transvaloração de todos os valores".

Explico-me: se todo discurso humano é mera perspectiva, mera interpretação, e não há critério absoluto ou universal permitindo comparar diferentes perspectivas e estabelecer, dentre elas, quais seriam "melhores" ou "piores", que sentido haveria em propor, afirmativamente - como Nietzsche me parece fazer -, um determinado conjunto de valores em detrimento de outro? Que sentido haveria, por exemplo, em dizer que a moral cristã é ruim, e contrapor-lhe uma moral boa, baseada em noções como autossuperação, além-do-homem, espírito livre etc.? A meu ver, o sentido desse projeto propositivo, por assim dizer, depende da adoção de um critério ainda subjetivo (no sentido moderno) como, por exemplo, a noção de saúde ou de afirmação da vida, para medir as perspectivas e selecionar, entre elas, as que melhor se adequem a ele (cf. Mattos, 2013, p. 86 e ss). É preciso lembrar que a crítica de

8 "Mas penso que hoje, pelo menos, estamos distanciados da ridícula imodéstia de decretar, a partir de nosso ângulo, que somente dele pode-se ter perspectivas. 0 mundo tornou-se novamente 'infinito' para nós, na medida em que não podemos rejeitar a possibilidade de que ele encerre infinitas interpretações” (Nietzsche, 2001, p. 278. Seção 374, “Nosso novo 'infinito’”). 
Nietzsche à moral cristã não se deve ao fato de ela ser falsa ou incorreta, mas sim ao fato de ser prejudicial à vida, de implicar uma negação doentia do viver e do querer; é a partir desse deslocamento de critérios, portanto, que ele pretende instituir um novo modo de valorar, mais favorável à afirmação da vida e da saúde.

Onde Kant, pois, estabelecia o imperativo categórico, princípio supremo da moralidade, como fundamento para pensar o mundo, e o viver humano no mundo, para além do estritamente observável nos marcos da ciência empírica, Nietzsche o substitui, por assim dizer, pelo critério da vida como fundamento para, de maneira análoga a Kant, estabelecer uma interpretação cosmológica (ou metafísica) do mundo que se sabe interpretação, que se sabe crença, mas que nem por isso deixa de reivindicar sua validade em face da necessidade humana de vivenciar o mundo e lhe dar um sentido (cf. Mattos, 2013, p. 105 e ss). A própria interpretação do mundo como vontade de poder, portanto, e - de maneira talvez mais clara - a ideia do eterno retorno do mesmo apresentam-se como hipóteses interpretativas cujo mérito estaria em firmar uma visão do mundo afirmativa, desprovida dos elementos tipicamente cristãos da culpa, da revolta, do desejo de que o mundo fosse diferente do que é. Mas elas me parecem ser, de fato, como apontaria Heidegger, hipóteses metafísicas que, desse modo, se colocam em relação de concorrência com as hipóteses cristãs, dominantes na história da civilização ocidental (cf. Heidegger, 2007, p. 195 e ss).

Nietzsche não se cansará de enfatizar, é certo, que elas são simplesmente as suas hipóteses, as suas verdades, mas essa ressalva epistemológica, por assim dizer, não muda o seu caráter enquanto chaves interpretativas que dão ao mundo um significado metafísico (ou "cosmológico", se se preferir). E um significado que permite pensar a vida de maneira afirmativa, instaurando assim um tipo de "ética da autenticidade", ou de autorrealização (Giacoia fala numa "estilística da existência”) (cf. Giacoia Jr., 2012), em que o indivíduo (ou um grupo, um povo, uma época?) pode traçar para si um destino próprio, com coragem e independência (características do "espírito livre" nietzschiano), e assim encontrar o sentido existencial que lhe é mais próprio, ou simplesmente “tornar-se o que é”, para usar a conhecida fórmula do subtítulo do Ecce Homo.

Desse ponto de vista, portanto, a chamada "cosmologia da vontade de poder" serviria ao propósito de libertar o ser humano da moralidade cristã e, assim, permitirlhe realizar-se de maneira mais plena e autêntica - donde o possível parentesco, a que me referi acima, entre a filosofia de Nietzsche e o projeto iluminista, que buscava libertar o homem do preconceito e da superstição e entregar-lhe as rédeas de sua própria existência. A rigor, Nietzsche seria inclusive, quanto a isso, mais radical do que o próprio Kant (o grande nome do Iluminismo alemão, o famoso defensor do sapere aude), já que teria identificado neste a sobrevivência das superstições cristãs, mal disfarçadas em seu imperativo categórico (que, como vimos, serve de base para 
a reafirmação das ideias - essencialmente cristãs, segundo Nietzsche - de Deus, alma e liberdade), e procurado libertar o ser humano também deste seu último grilhão (ou seja, a racionalidade como um padrão universal e uniformizante).

Isso nos permitiria chegar talvez ao extremo (ao absurdo, segundo alguns leitores de Nietzsche!) de aproximar a defesa nietzschiana da "liberdade em sentido perspectivista” (ou seja, a referida liberdade de estabelecer o próprio modo de ver e viver o mundo) à democracia moderna, tão duramente criticada por Nietzsche: se o que queremos, como ele propõe, é a liberdade de instituir novas perspectivas, e a diversidade destas, então seria preciso assegurar direitos mínimos aos indivíduos, de modo a garantir-lhes essa possibilidade mesma de criação. Se eles não tivessem, por exemplo, liberdade de pensamento e de expressão, e um mínimo de liberdade quanto à autodeterminação de seu modus vivendi, eles não poderiam tornar-se "espíritos livres" buscando superar-se cada vez mais, guiados pelo ideal do "além-do-homem" etc. (cf. Mattos, 2008).

Mas esse "excurso político", por assim dizer, não é o que me interessa frisar aqui. O que me interessa mais fortemente é o vínculo, acima delineado, entre a possibilidade de pensar o mundo para além do estritamente observável (o domínio fenomênico de Kant, a mera perspectiva científica cujos limites Nietzsche reconhece), motivada pela nossa necessidade de dar-lhe um sentido (um sentido moral em Kant, um sentido de autenticidade singular em Nietzsche), e a construção positiva de uma interpretação metafísica do mundo (uma metafísica cristã em Kant, uma metafísica anticristã em Nietzsche). Pois isso nos permitiria atestar a importância da metafísica no interior do próprio projeto iluminista; no interior, portanto, de uma reflexão voltada a pensar a moral e a política.

\section{Dieter Henrich versus Jürgen Habermas: pelo renascimento da metafísica}

Trazendo essa discussão para o cenário contemporâneo, chama particularmente a atenção a polêmica travada entre Jürgen Habermas e Dieter Henrich nos anos 1980: depois de este último, que até então se destacara como um brilhante historiador da filosofia, publicar em 1982 o livro Fluchtlinien ("Linhas de fuga”), conclamando a um retorno à metafísica, aquele reagiu de maneira contundente, escrevendo uma resenha com fortes críticas à ideia de ressuscitar a metafísica, que estaria morta há bastante tempo. Henrich revidou o golpe com o artigo "O que é metafísica? 0 que é modernidade? Doze teses contra Jürgen Habermas” (Henrich, 2009), no qual defende um vínculo indissociável entre a filosofia e as questões metafísicas, considerando que, se estas forem abandonadas, também a filosofia o será. Habermas reagiria ainda outra vez, com novo artigo contra a metafísica que seria publicado, juntamente com o primeiro e outros textos, no livro Pensamento pós-metafísico, cuja tese de fundo 
é justamente a de que vivemos uma era pós-metafísica, em que já não faria sentido falar sobre coisas como a essência do mundo, o sentido da vida, etc. (questões que se restringiriam hoje, quando muito, à vida privada de cada um) (cf. Habermas, 1990).

Naturalmente, a posição de Dieter Henrich se alinha melhor ao que vínhamos sugerindo anteriormente quanto à necessidade de pensar os pressupostos metafísicos da visão de mundo que adotamos - que necessariamente adotamos - quando pensamos a moral e a política. Note-se que não se trata, na posição de Henrich, de defender a metafísica contra a modernidade e seu mundo "desencantado", ou como uma alternativa a ele, mas sim de entendê-la como o pano de fundo teórico mais amplo por trás do próprio projeto moderno, isto é, o projeto iluminista (aquele mesmo que, segundo vimos, teria animado os projetos filosóficos tanto de Kant como de Nietzsche). Seria preciso assumir, em outras palavras, uma metafísica cujo objeto não é o "mundo em si mesmo" (cujo conhecimento Kant teria vedado), mas o modo como nós, seres humanos, pensamos o "mundo em si mesmo", de modo a dar um sentido à vida que levamos no "mundo fenomênico" (o único que conhecemos) (cf. Mattos, 2009).

Ou seja: no contexto pós-kantiano, a metafísica de que se trata não é a metafísica clássica, ocupada de conhecer Deus, o mundo em si e a alma humana como objetos a que tivéssemos acesso do mesmo modo como o temos à mesa, à cadeira ou ao nosso corpo; ela é antes uma reflexão humana, sobre o mundo e seus limites, que parte de nossa própria necessidade subjetiva de pensá-lo e dar-lhe um sentido. Que isso não seja um exercício vazio e arbitrário, em que cada um pode criar a sua metafísica pessoal e considerá-la tão válida quanto qualquer outra (uma objeção bastante plausível, e que, aliás, é levantada por Heidegger), seria garantido pelo "conhecimento" que temos da experiência histórica por nós partilhada - a que temos "acesso", por exemplo, na história da filosofia, das religiões e da arte (âmbitos de reflexão ou expressão em que se coloca em jogo o sentido da existência).

\section{A ontologia fundamental: o Ser e Tempo de Martin Heidegger}

Com isso, porém - um ouvinte atento já o terá notado -, começamos a mover-nos para fora do âmbito nietzschiano, tal como acima esboçado: se podemos falar de uma experiência partilhada do mundo como base "objetiva" para o tipo de "conhecimento" que estaria em jogo na metafísica, já não se trata de um perspectivismo puro e simples, em que a singularidade pudesse servir de base para novos discursos sobre a realidade (naquele sentido de que esta teria voltado a ser "infinita" para nós), e em que espíritos livres pudessem brotar por aí, anunciando corajosamente as suas "verdades". Também não se trata, por outro lado, de um retorno ao "conhecimento prático" kantiano, lastreado numa concepção universalista da racionalidade humana 
que nos permitisse "preencher" o "suprassensível" com objetos como Deus, alma e liberdade. Pois já não estamos lidando com uma subjetividade definida e estável, que permanecesse a mesma ao longo dos tempos: trata-se agora de uma experiência histórica partilhada, e de uma experiência que se deu - e se dá - no mundo em geral (o qual não pode, pois, ser colocado entre parênteses).

Ou seja: nós existimos no mundo, e o tema da "metafísica” (ou já deveríamos dizer "ontologia"?) é o sentido desse existir, que "conhecemos" (ou compreendemos) em função de nossa experiência partilhada disso. Mas como comprovar esse conhecimento? - perguntará, ansioso, o empirista de plantão. E a nossa resposta será que, de fato, não temos como comprová-lo - o que não significa, todavia, que o seu "objeto" seja inacessível, ou esteja além de nossa percepção (como dizia Kant da coisa em si). Ele apenas não obedece ao mesmo "regime de verdade", por assim dizer, do conhecimento empírico ou científico: onde este opera com enunciados representativos que devem corresponder a coisas no mundo - ou "estados de coisas", para falar com o primeiro Wittgenstein -, a ontologia fenomenológica (sim, já falamos aqui com Heidegger) opera com descrições não representativas que permitem ver aspectos mais complexos do mundo - um mundo que, ao vivenciar, somos capazes de "compreender" (no sentido de abarcar com a visão, ou aquilo que Heidegger caracteriza como “circunvisão”, Umsicht) (cf. Heidegger, 2004, p. 149 e ss).

Também aqui, como em Kant ou Nietzsche, estamos nos opondo à redução empirista ou positivista do real ao "empiricamente observável”; mas, ao contrário do que ocorria lá (onde a verdade ainda era compreendida como correspondência entre linguagem e mundo), não precisamos ir além do empiricamente observável (para aí encontrar o Deus kantiano ou a vontade de poder nietzschiana): o mundo é o mesmo, os objetos são os mesmos, nós somos os mesmos; o que muda é o modo de interpretálos - ora como "coisas", isoladas de seu contexto pelo olhar perscrutador do cientista (ponto de vista ôntico); ora como existências temporalmente determinadas cujo ser está aí, diante de nós, em nós, conosco (ponto de vista ontológico) (cf. Heidegger, 2012, p. 31 e ss). O ser é, nós somos - nós o vivenciamos e o compreendemos. E isso é algo que escapa à linguagem representativa, conceitual, que é própria tanto ao conhecimento científico como à metafísica, enquanto o discurso encobridor do ser que se estabeleceu na história ocidental (a ciência e a metafísica são, na verdade, duas faces da mesma moeda), bem como também ao senso comum do homem moderno (impregnado que é dessa mesma linguagem). É preciso encontrar, pois, uma outra linguagem para exprimi-lo - talvez a da religião, talvez a da poesia, talvez a da arte em geral (um problema com que o segundo Heidegger se verá às voltas). Mas é preciso, antes de tudo, apontar para isso - e isto é algo que Ser e Tempo certamente faz. 


\section{Três observações finais}

1) Pode-se dizer que Nietzsche já não se move no registro da verdade como correspondência (que ele de fato critica), e que, a exemplo de Heidegger, encontra nos pré-socráticos um registro alternativo a esse (o registro da verdade como desvelamento) e também está em busca de uma outra linguagem para exprimir a verdade do ser. Talvez isso seja certo a respeito de Nietzsche, ou de um certo Nietzsche. Mas não é o caso do Nietzsche tal como o interpreto, o qual, vinculado à tradição subjetivista, ainda teria pensado a verdade em termos de uma interpretação que, de algum modo, representa conceitualmente o mundo - valendo-se de noções como vontade de poder e eterno retorno do mesmo, por exemplo. Desse ponto de vista, eu teria aceito a leitura que o próprio Heidegger faz de Nietzsche, acusando-o de, justamente por isso, não ter superado a metafísica ocidental, sendo antes o "último metafísico do Ocidente".

2) Pode-se dizer que Kant vislumbrou a diferença ontológica (esta que Heidegger estabeleceentreoponto devistaônticoeoontológico)ao diferenciar, nosProlegômenos, os juízos de experiência (em que o objeto é configurado como objeto propriamente dito, a serviço do conhecimento empírico) e os juízos de percepção (em que teríamos uma abertura prévia ao mundo fenomênico, anterior, portanto, ao "encapsulamento ôntico" dos objetos). Algo semelhante se poderia dizer talvez da diferença entre juízos determinantes (próprios do conhecimento científico) e juízos reflexionantes (em que nossa reflexão sobre o mundo natural - não sobre o suprassensível - se pauta por critérios distintos dos científicos). Mas, ao manter a distinção forte entre o sensível e o suprassensível, e ao pensar Deus e alma como objetos deste último, Kant se teria mantido na chave ontoteológica que caracteriza a metafísica ocidental como um todo.

3) Assim como em Kant e em Nietzsche, também me interessa, evidentemente, pensar em Heidegger os desdobramentos éticos de sua filosofia. Ainda que muitos relutem em enxergar um viés normativo em Ser e tempo, minha tendência é apontar para uma diferença valorativa entre a atitude autêntica, positiva, e a inautêntica, negativa: para quem passou pelo sentimento de angústia e descobriu a possibilidade de seu ser mais próprio, escolher este caminho é preferível a deixar-se absorver novamente pelo ponto de vista da impessoalidade (ainda que isto seja inevitável em boa parte do tempo). Nesse sentido, seria possível estabelecer um claro paralelo entre o espírito livre nietzschiano, que se realiza num caminho autêntico (lastreado na sua singularidade vivencial), e o indivíduo que, na terminologia de Heidegger, assume o seu ser próprio e também realiza um caminho peculiar. Mas isso é algo a ser desenvolvido em outra ocasião. 


\section{Referências:}

Freuler, L. (1992). Kant et la métaphysique spéculative. Paris: Vrin.

Giacoia Jr. (2012). O. Nietzsche versus Kant: uma disputa permanente a respeito de liberdade, autonomia e dever. Rio de Janeiro: Casa do Saber.

Habermas, J. (1990). Pensamento pós-metafísico: estudos filosóficos. Rio de Janeiro: Tempo Brasileiro.

Heidegger, M. (2004). Ser e tempo, parte I. Tradução de Márcia S.C. Schuback. Petrópolis: Vozes.

- (2007). Nietzsche, vol. II. Tradução de Marco A. Casanova. Rio de Janeiro: Forense Universitária.

. (2012). Os Problemas Fundamentais da Fenomenologia. Tradução de Marco A. Casanova. Petrópolis: Vozes.

Henrich, D. (2009). O que é metafísica? O que é modernidade? Doze teses contra Jürgen Habermas. Tradução de Fernando C. Mattos. Cadernos de filosofia alemã, 14, pp. 83-117.

Hulshof, M. (2013). A coisa em si entre teoria e prática: uma exigência crítica. Tese de doutorado defendida no Depto. de Filosofia da USP.

Kant, I. Prolegomena zu einer jeden künftigen Metaphysik die als Wissenschaft wird auftreten können. In: Akademie Ausgabe, vol. IV.

VIII.

. Was heisst, sich im Denken orientieren? In: Akademie Ausgabe, vol.

- (2009). Fundamentação da Metafísica dos Costumes. Tradução de Guido A. de Almeida. São Paulo: Barcarolla.

Petrópolis: Vozes.

- (2012). Crítica da razão pura. Tradução de Fernando C. Mattos.

. (2013). Metafísica dos costumes. Tradução de Bruno Nadai, Diego Kosbiau, Monique Hulshof. Petrópolis: Vozes.

Petrópolis: Vozes.

- (2016). Crítica da razão prática. Tradução de Monique Hulshof.

Lebrun, G. (1993). Sobre Kant. Tradução de Rubens R. Torres Filho. et alii. São Paulo: Iluminuras.

(2002). Kant e o fim da metafísica. Tradução de Carlos A. R. de Moura. São Paulo: Martins Fontes.

Marton, S. (2000). Nietzsche. Das forças cósmicas aos valores humanos. Belo Horizonte: Ed. UFMG.

Mattos, F. (1999). Kant e o problema da coisa em si. Perspectiva de uma reflexão racional. Cadernos de Filosofia Alemã, 5, pp. 27-44.

. (2007). Pensando Nietzsche a partir de Kant: uma radicalização do projeto crítico? Cadernos de filosofia alemã, 10, pp.51-86. 
- (2008). Perspectivismo e democracia: uma breve reflexão sobre a política a partir do espírito livre nietzschiano. Cadernos de filosofia alemã, 12, pp.79-98.

. (2009). Da teoria à liberdade: a questão da objetividade em Kant. São Paulo: AM Ed..

. (2009a). Intersubjetivismo versus subjetivismo? Algumas considerações sobre a controvérsia Habermas-Henrich a partir das "12 teses". Cadernos de filosofia alemã, 14, 2009, pp.55-82.

- (2013). Nietzsche, perspectivismo e democracia: um espírito livre em guerra contra o dogmatismo. São Paulo: Saraiva.

Nietzsche, F. (1980). Obras incompletas (coleção “Os pensadores”). Tradução de Rubens R. Torres Filho. São Paulo: Abril Cultural. . (2001). A gaia ciência. Tradução de Paulo César de Souza. São Paulo: Cia. das Letras.

Recebido em: 21.05.2018

Aceito em: 08.09.2018

Esta obra está licenciada com uma Licença Creative Commons Atribuição-NãoComercial- 